都市域小河川に対する住民意識とその变化

Inhabitant Senses for River Environment in Urban Area and its Changes

\begin{tabular}{|c|c|c|c|c|c|}
\hline ;崎大学工学部 & 杉 & 尾 & & 哲 & Satoru SUGIO \\
\hline 大学工学部 & 波 & 多 & 義 & 春 & Yoshiharu HATA \\
\hline 州大学工学部 & 小 & 松 & 利 & 光 & Toshimitu KOMATL \\
\hline
\end{tabular}

The questionaires are collected from the Komatu river basin in 1985 and 1989 to investigate the inhabitant senses for the river environment in an urban area. These data are anayzed by the Quantitative and Mathematical Methods. From the analysis, the followings are clarified: i)The inhabitants prefer the familiarity with water to the flood control. ii) The preference is essentially unchanged with time and depends on their inhabited district. iii)They are sensitive in the sense to the improvement of their life circumstances. Keywords:inhabitant sense, river environment, quantitative and mathematical methods

\title{
1.まえがき
}

河川に对する行政の方向は、これまでの、流域住民の生活空間を保持するための治水機能と利水機能を優 先する考え方から、水辺の重要性を認識して親水機能を含めた総合的な機能を発揮させる考え方に変わって きた。一方、流域住民の河川に対する意識は様々であるが、意識そのものが河川および流域の生活基盤の整 備状況に直接的に左右されることが考えられる。このような状況の中で、流域の都市化が進行することによ って生活排水の負荷と降雨時の河川流量が增大している都市域小河川に対して、流域住民がどのような意識 を持ち、流域内の整備が進むことによって、その意識がどのように変化してゅくかが注目される。本研究は 宮崎市の市街部を流れる小松川を対象として、河川に対する意識調查を1985年と1989年に実施し、その解析 結果から、流域の住民意識の把握および住民意識と地区特性との对応を検討するとともに、両調査結果を比 較することによって住民意識の変化を調べたものである。

\section{2. 調查对象流域の状況}

調査対象流域として、図 1 に示す、大淀川の左支川で宮崎市の市街 地を流れる小松川の流域を選んだ。小松川は、流域面積が $4.65 \mathrm{~km}^{2}$ 、 流路延長 $5.0 \mathrm{~km}$ 、同落差 $7.0 \mathrm{~m}$ の、上流域にかん善源を持たない典型的 な都市域小河川であり、次のような状況にある。

(1)1983年に発生した内水氾濫状況の再現計算の際に推定した河道の 通水能力は、年最大時間降水量の再現期間で 2 年程度と小さく ${ }^{1)}$ 、流 域が現在のように都市化する以前から内水災害が頻発している。(2)降 雨時に大淀川の水位が上昇すると、大淀川外水の堤内への遡上を防ぐ ために、小松川合流地点の㭪門を閉じることになるが、排水機が設置 されていないため、その後は小松川から排水できなくなる。(3)かって、 流域の急速な都市化に伴う家庭排水の增加によって河川水質が悪化し、 河床にへドロが堆積して悪臭を発する状態となったため、水質の保全 と河川景観の保持を目的とした浄化用水が、1981年より図 1 の大淀川 の a 地点から $0.7 \mathrm{~m}^{3} / \mathrm{s} 、 1984$ 年より b 地点から $0.3 \mathrm{~m}^{3} / \mathrm{s}$ の合計 $1.0 \mathrm{~m}^{3} / \mathrm{s}$ が揚水されて流下している2)。(4)1984年に「大淀川をきれいにする条 例」が宮崎市によって制定された。(5)流域内の下水道整備事業が1986

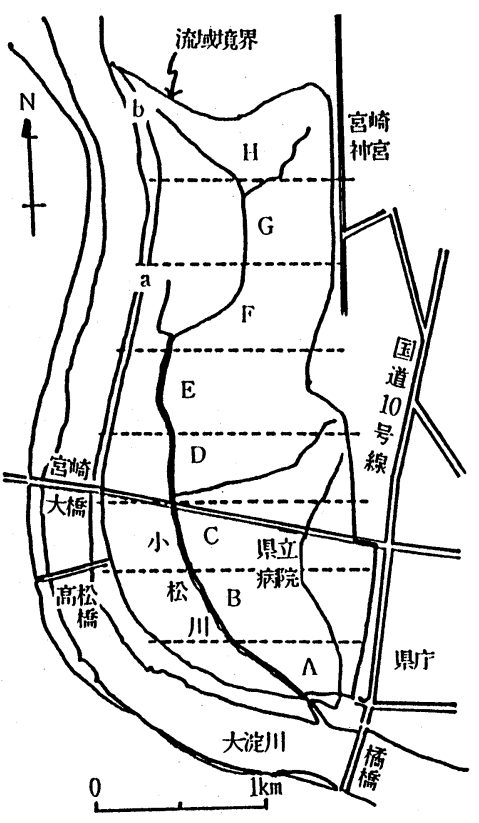

図 1 調查对象流域 (英文字は地区名称) 
年に着手され、1989年度に完了する。(6)小松川合流地点の排水整備事業が1987年に着手され、1991年から稿 锄する。(7)1989年7月末に台風11号が鹿児島県大隅半島に上陸して大淀川流域に大雨を降らせ、宮崎水位観 測所の最高水位が計画高水位6.34mにせまる5. $46 \mathrm{~m}$ に達した ${ }^{3)}$ 。(8)1989年の夏休みに、小松川合流点の直上 流の大淀川左岸高水敷に、親水会園遊泳場“)が開設され好評であったが、台風による增水で、夏休み期間中 の約半分の期間しか利用できなかった。

3.アンケート調查および解析手法

小松川流域の住民が持つ都市域小河川に対する意識がどのようなもので、それが当流域における排水施設 整備事業や下水道整備事業などの進路によってどのように変化してゆくかを知るために、1985年春と1989年 初秋にアンケート調查を実施して比較した。アンケート調查票は、(1)河川に対する関心、(2)水害に対する危 機感の有無、(3)河川の水質状況に対する満足感、に对する反応を抽出しようとするもので、1985年と1989年 の調查とも同じ調查票 ${ }^{5)}$ を使用した。

河川に対する関心をたずねる調查票 1 は、表 1 に示すような河川に関する15種の言葉について、特に関心 の深いものを好きなだけ選ばせることにより、流域住民の河川に対する潜在意識を求めようとするものであ ク、治水機能、利水機能および親水機 能に係わる一般的な言葉が並べられて いる。

水害に対する危機感の有無をたずね る調査票 2 は、水害に対する危機感の 有無を外的基準とし、水害に係わる諸 表 1 調查票 1 の河川に関する言葉

\begin{tabular}{|c|c|c|}
\hline 1.河川の水位 & 2. 洪水の起こる回数 & 3.ダムや貯水池での流量調整 \\
\hline 4. 河床の低下 & 5. 河道の改修計画 & 6.潤いのある景観 \\
\hline 7.散歩の場所 & 8. 魚釣りの場所 & 9. 子供の水遊びの場所 \\
\hline \multirow{2}{*}{\multicolumn{2}{|c|}{$\begin{array}{l}\text { 10. 排水の流入による河川水の污染 } \\
\text { 12. 農業用水への利用 }\end{array}$}} & 11. 水道水への利用 \\
\hline & & 13. 工業用水や発電用水への利用 \\
\hline \multicolumn{2}{|c|}{ 14. 周辺の地下水との関係 } & 15. 排水路としての利用 \\
\hline
\end{tabular}

施設の整備状況に対する満足感や水害の経験あるいはサンプルの水害に対する関心度などを説明変量にして 、危機感の有無がどのアイテムに支配されているかを調べ、また、危機感意識を比較的に強く持つサンブル と持たないサンブルが、流域内のどこに住んでいるかを調べようとするものである。

河川の水質状況に対する満足感をたずねる調査票 3 は、河川の水質状況に对する満足感を外的基準とし、 水質に係わる諸施設の整備状況や河川の水質浄化に対する関心などを説明変量として、水質の満足感がどの アイテムに支配されているかを調べ、意識の高いサンブルの居住分布を求めようとするものである。

アンケートのサンプルは流域内から無作為に抽出し、1985年は面接調查法で、1989年は配票調査法で収集 した ${ }^{6)}$ 。収集したサンプル数は1985年は212であり、1989年は412である。解析は多変量解析の数量化理論 7 を用いた。調査票 1 の河川に対する関心の分析は河川に関する言葉の質的変量とサンブルの両方を分類する もので、外的基準が存在しないため、数量化理論第III類を用いた。調查票 2 と 3 の、それぞれ水害に对する 危機感の有無と河川の水質状況に対する満足感の分析は、ともに質的な外的基準をもち、説明変量が質的変 量であることから、数量化理論第 II 類を用いた。

4. 河川に对する意識構造の分析

調查票 1 で得た治水・利水・親水に保わる 15 種類の言葉についての流域住民の反応から、カ テゴリー数量とサンプル数量を求め、住民の潜 在的な志向意識とその構造を分析した。この解 析では固有値問題となるため、固有値の大きい ほうから 3 つの固有ベクトルを選んでカテゴリ 一数量とし、これを三次元座標軸上に表示する と、1985年と1989年の調查結果は図2のように なる。図中の各カテゴリー間の距離がカテゴリ 一の類似性を示しているから、互いに近いカテ

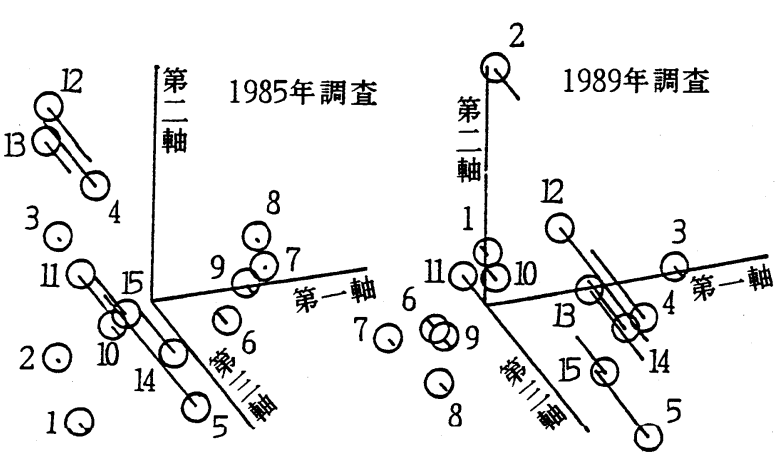

図2 意識構造の三次元表示 (数字は表 1 のカテゴリーの番号) 

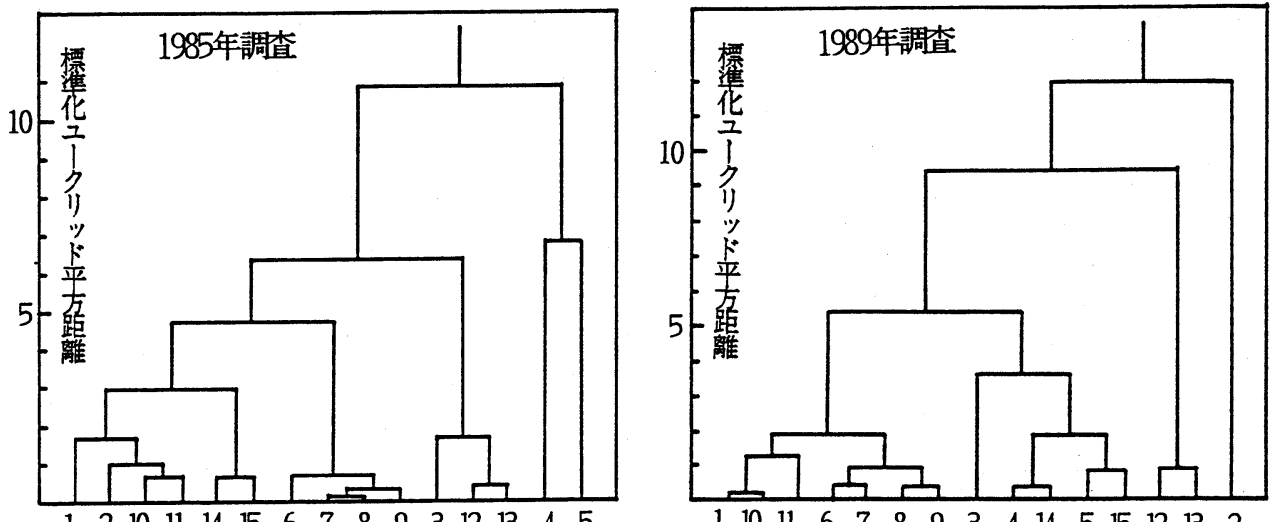

$\begin{array}{llllllllllllllll}1 & 2 & 10 & 11 & 14 & 15 & 6 & 7 & 8 & 9 & 3 & 12 & B & 4 & 5\end{array}$

$\begin{array}{llllllllllllllll}1 & 10 & 11 & 6 & 7 & 8 & 9 & 3 & 4 & 14 & 5 & 15 & 12 & \mathrm{~B} & 2\end{array}$

図 3 意識構造の樹形困 （横軸の数字は表 1 のカテゴリーの番号）

ゴリーほど住民から類似の力

テゴリーであると反応されて いることを示している。困中 には、各カテゴリーの空間位 置を分かり易くするために、 第一軸 - 第二軸平面からの隔 たりを実線で示している。ま た、これらのカテゴリーの分 類をより明確にするために、 カテゴリ一数量を用いてクラ スタ一分析 ${ }^{8)}$ を行い、非類似 度を群平均法で定義して樹形 困に表示したものが図3であ
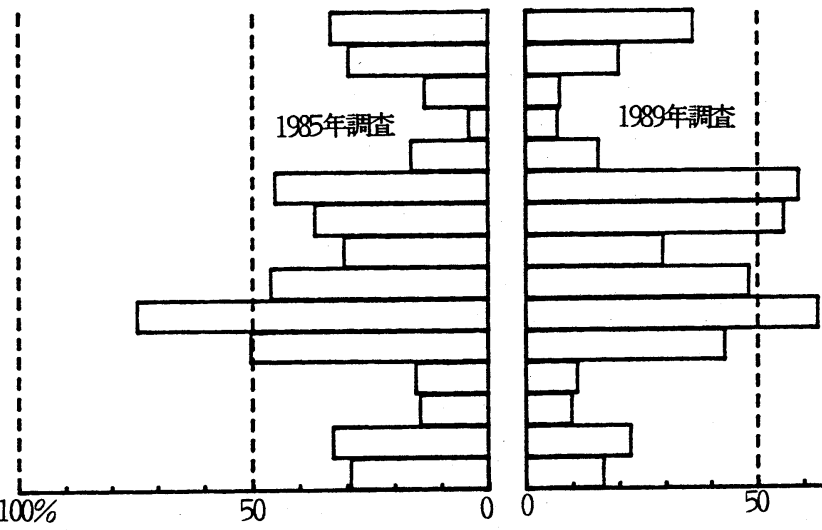

図4 流域住民の関心の度合い

河川水位 洪水の回数 夕人流量調整 河床の低下 河道の改修 潤いの景観 散步の場所 魚釣りの場听 水遊じの場所 河川水の污染! 水道への利用 農業への利用! 工業への利用! 地下水と関係， 排水路に利用 $100 \%$

る。さらに各カテゴリーに対する流域住民の関心の度合いを、各カテゴリ一毎に反応したサンプル数を全サ ンプル数の百分率で表現して示したものが図 4 である。

これらの結果からカテゴリーを分類すると、まず親水機能に係わる言葉の6〜9(表 1 の番号、以下同様)

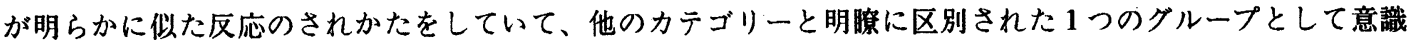
されており、しかも関心が高くなっていることが分かる。このグループに連関して同等以上に関心が高い力 テゴリーとして1,10,11を基本とするグループがあり、これに、関心は低くなるが14,15を基本とするグルー

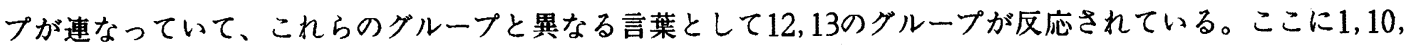
11 河川水質に係わる言葉として認識されていて、12,13は流域に無関係な利水機能に係わる言葉として認 識されている。また調査票作成時には1〜5は治水に係わる言葉として選定したが、これらの言葉は明瞭なグ ループを形成せず、いろいろに解釈されて上記の各グループに分散して現れている。1985年と1989年の調査 結果を比較すると、これらの意識構造は細部で変化しているものの、ほぼ同じであり、グループの意識連鎖 も変化していない。図4 に示した関心の度合いも同じであるが、「閏いのある景観」と「散歩の場所」のア イテムに対する関心が高くなっている点が注目される。

以上のように、治水、利水、親水の 3 つのグルーブに属すると考えた15個のカテゴリーが、ほほ 4 つのグ ループに分類して反応されていて、親水 $\rightarrow$ 水質 $\rightarrow$ の他の意識連鎖になっていると考えられる。注目すべき は、治水よりも親水に関心が高い点であり、住民は数年に一度の割合で住環境を破壊する水災害よりも、日 常的に住環境を污染している小松川の水質状況の改善を志向し、情緒的な河川空間の創造を志向していると 


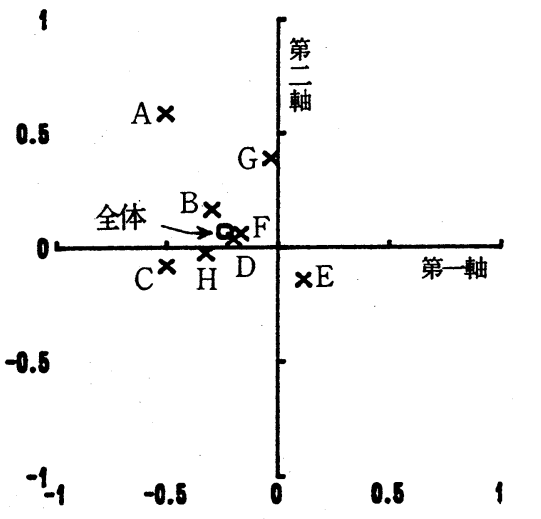

図 5 地区毎のサンプル数量の平均値 考えられる。

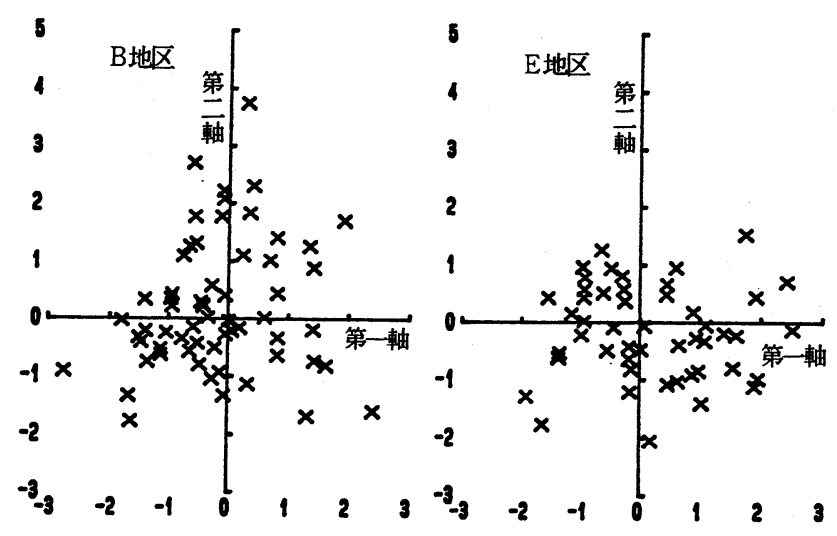

図 6 サンプルの志向性

次に、カテゴリー数量から求めたサンプル数量を図 2 と同じ座標軸に描いて、流域住民の志向性を求めた。 図 2 中のカテゴリーの位直とカテゴリーのグループの解釈から、座標軸がどのような志向性を表しているか を求めると、1985年と1989年の調査結果で軸の方向が異なるが、1989年の調查結果では第一軸の(ー)方向が 親水性志向を、第二軸の(十)方向が治水性志向を表していることは明らかである。このように座標軸を解釈 して、流域全体のサンプル数量を座標軸上に描くと、住民の志向は広く分散し、流域内には様々な潜在意識 をもった人々が混在していることが分かる。これを地区毎にプロットすると、地区毎の傾向が現れてくる。 図 5 は地区毎にサンプル数量の平均値を求めて示したもので、図中の○印が流域全体の平均値である。図 6 は B 地区と $\mathrm{E}$ 地区を選んで、サンプルの志向性を示したものであり、これから B 地区には治水性志向の強い サンプルが多く住んでいることが分かる。流域全体の志向性と比較すると、A～C $\mathrm{H}$ 地区で親水性志向、 $\mathrm{A}, \mathrm{B}, \mathrm{G}$ 地区で治水性志向、 $\mathrm{E} \sim \mathrm{G}$ 地区で利水性志向のサンプルが多いと判定される。この傾向は、それら ・の地区が、それぞれ、比較的古くから市街化していた地区、内水災害が類発する地区、比較的新しく市街化 された地区であることを考虑すると、それぞれの地区の特性と良く対応している。

5. 水害に対する危機感の有無の分析

水害に対する危機感の有無を外的基準として解析すると各カテゴリーのカテゴリー数量が得られ、各アイ テムのRangeと偏相関係数が表 2 のように得られる。困 7 は各アイテムの偏相関係数を図示したものであり、

「大雨時の流れへの注意」のアイテムが他のア イテムよりも大きく外的基準に寄与していて、 1985年と 1989年の調査結果に変化がないことが 分かる。これに対し、1985年の調査結果では

「河川堤防の整備状況」、「排水施設の整備状 況」、「水源地の治水対策」、水害避難の経験」 も大きな値を示していたが、1989年の調査結果

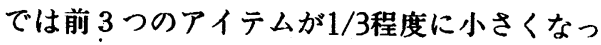
ている。ここに、1985年の調査と1989年の調査 との間に、流域住民の陳情に答える形で小松川 合流地点での排水施設の整備事業が1987年に着 エされ、すでに排水樋門の增設と排水機場の建 物が完成し、排水機の設置工事中であることを 考慮すると、この整備事業によって住民意識が
表 2 水害の危機感に対する解析結果

\begin{tabular}{|c|c|c|c|c|c|c|c|c|}
\hline \multirow{2}{*}{\multicolumn{4}{|c|}{ アイテム }} & \multirow{2}{*}{$\begin{array}{l}\text { 水 } \\
\text { 準 }\end{array}$} & \multicolumn{2}{|c|}{ 1985年調査 } & \multicolumn{2}{|c|}{ 1989年調査 } \\
\hline & & & & & \multicolumn{2}{|c|}{ Range E明酸 } & \multicolumn{2}{|c|}{ 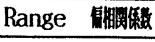 } \\
\hline 1 & \multicolumn{3}{|c|}{ 河川堤防の整備状況 } & 3 & 0.829 & 0.184 & 0.363 & 0.071 \\
\hline 2 & \multicolumn{3}{|c|}{ 排水施設の整備状況 } & 3 & 0.953 & 0.229 & 0.302 & 0.056 \\
\hline 3 & \multicolumn{3}{|c|}{ 水源地の治水対策 } & 3 & 1.519 & 0.231 & 0.409 & 0.067 \\
\hline 4 & \multicolumn{3}{|c|}{ 水害警報伝達の組織 } & 3 & 0.347 & 0.073 & 0.505 & 0.088 \\
\hline 5 & \multicolumn{3}{|c|}{ 公共避難所の整備状況 } & 3 & 0.562 & 0.112 & 0.615 & 0.123 \\
\hline 6 & \multicolumn{3}{|c|}{ 居住年数 } & 3 & 0.353 & 0.082 & 0.139 & 0.028 \\
\hline 7 & \multicolumn{3}{|c|}{ 水害避難の経験 } & 2 & 0.986 & 0.199 & 0.768 & 0.139 \\
\hline 8 & \multicolumn{3}{|c|}{ 公共避難所の知識 } & 2 & 0.300 & 0.074 & 0.223 & 0.049 \\
\hline 9 & \multicolumn{3}{|c|}{ 水害に備えての準備 } & 2 & 0.349 & 0.059 & 0.489 & 0.083 \\
\hline 10 & \multicolumn{3}{|c|}{ 気象情報への注意 } & 2 & 0.364 & 0.035 & 0.159 & 0.010 \\
\hline 11 & \multicolumn{3}{|c|}{ 大雨時の流れへの注意 } & 2 & 1.305 & 0.326 & 1.528 & 0.326 \\
\hline \multirow{2}{*}{\multicolumn{2}{|c|}{ サンプル数 }} & 外的 & 危機感 & & \multirow{2}{*}{212} & 109 & \multirow{2}{*}{412} & 243 \\
\hline & & 基準 & 伦機感 & & & 103 & & 162 \\
\hline \multicolumn{5}{|c|}{ 相関比 } & \multicolumn{2}{|c|}{0.257} & \multicolumn{2}{|c|}{0.209} \\
\hline
\end{tabular}


変化したものと考えられる。また1989年の調查前に記 録的な出水があったにもかかわらず「河川堤防の整備 状況」の偏相関係数が「大雨時の流れへの注意」のア イテムに比べて明瞭に小さくなっている点から、流域 住民の多くが大淀川の河川堤防を信頼していて、水災 害という言葉から大淀川の外水災害を想起せず、小松 川の内水災害を想起していると考えられる。

次に、1985年の調查結果から、各サンプルのサンプ ル数量を度数分布で示すと図 8 のようになる。危機感 ありと反応したグループと危機感なしと反応したグル

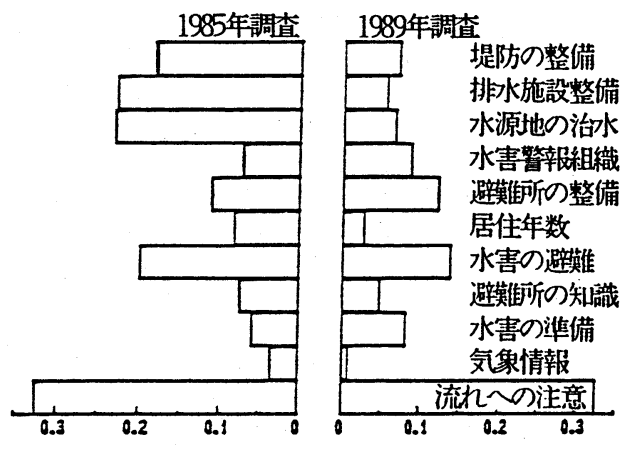

図 7 水害の危機感に対する偏相関係数 一プが重なっていて、あまり良くグループを判別できていな い。判別境界值は、危機感ありと反応したグループのサンブ ル数量の平均値がー0.493で、危機感なしと反応したグルー プ平均値が0.522であるから、0.015となる。いま危機感あ15 クのグループに属してサンプル数量がー0.493以下のサンプ ルと、危機感なしのグループに属してサンブル数量が0.522 以上のサンプルは、流域住民の中で意識が明瞭なものと考え、 これらの居住地を調べると図9のようになる。危機感ありの グループは明らかに小松川の右岸側に多く、危機感なしのグ ループは左岸側に多い。これは右岸側の地盤標高が左岸側よ

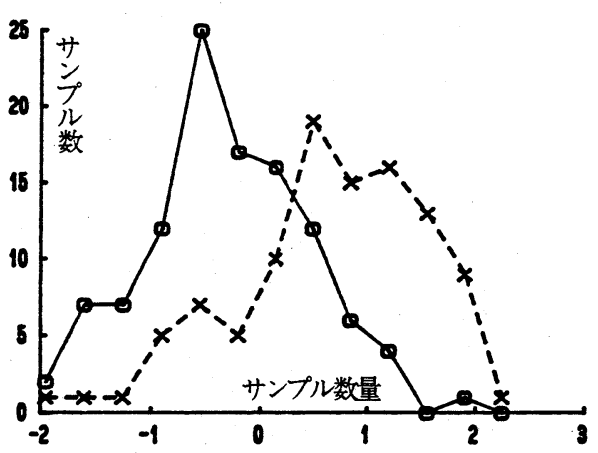

目 8 サンプルの度数分布 り低く、内水氾濫が起こりやすい状況にあることと良く符合している。

6. 河川の水質状況に対する満足感の分析

河川の水質状況に对する満足感を外的基準として解析すると各カテゴリーのカテゴリー数量が得られ、各 ・アイテムのRangeと偏相関保数が表 3 のように得られる。図10は各アイテムの偏相関係数を図示したもので ある。1985年の調査結果では「下水道の整備状況」のアイテムの偏相関係数 が他のアイテムに比べて非常に大きくなっていて、「排水溝の掃除」と「河 床の整備状況」のアイテムが約半分の大きさで続いていたものが、1989年の 調查では「河床の整備状況」と「污染源の浄化对策」の偏相関係数が大きく なって、「下水道の整備状況」は1/2 1/3に小さくなり、「排水淟の掃除」 は極端に小さくな 表 3 河川水質に対する解析結果

つている。すなわ ち1985年の調査時 点では、流域住民 の多くが流域内で 下水道の整備をお こなえば小松川の 水質問題は解決す ると考えていたも のが、下水道の整 備が進んでも小松 川の河川景観が改 善されないのに気

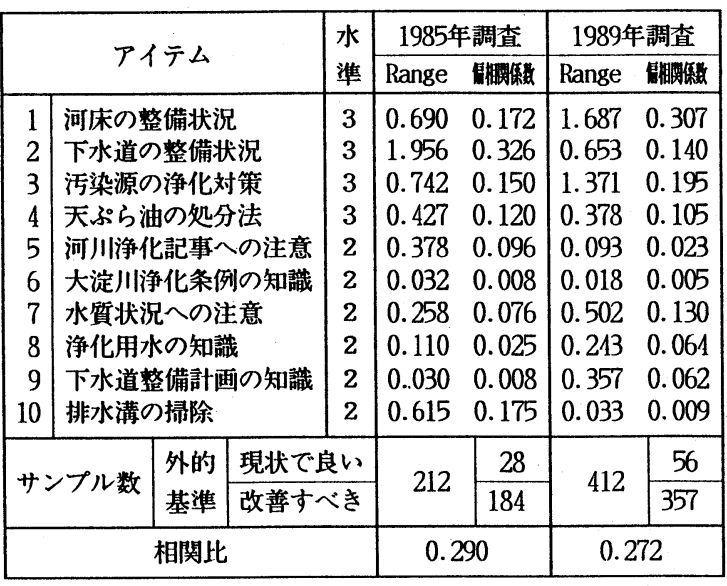

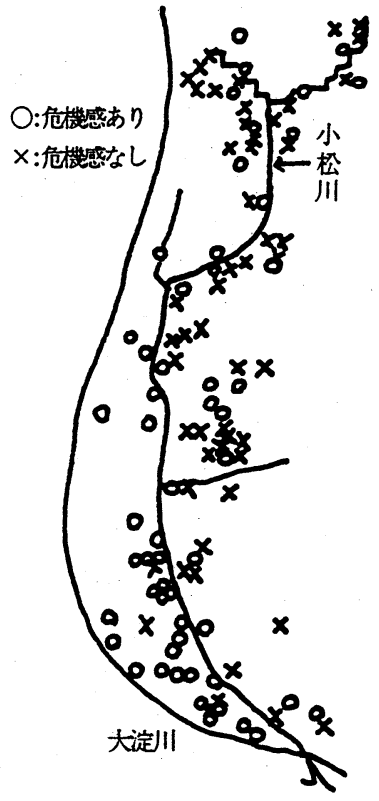

困 9 水害意識が明瞭な サンプルの居住地 

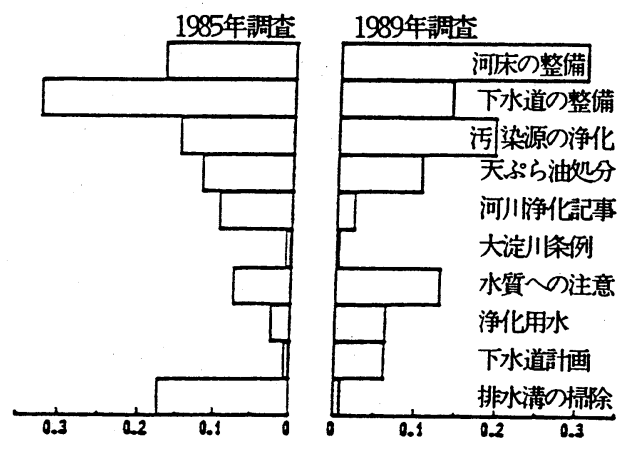

图10 水質の満足感に対する偏相関係数

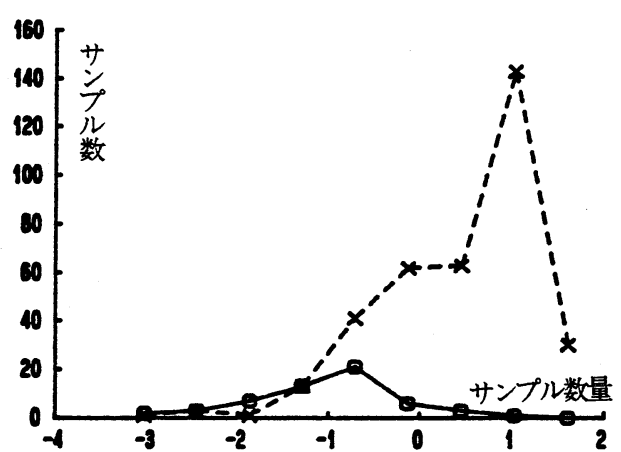

目11 サンプルの度数分布

付くとともに、小松川合流地点の近くに親水河川プールが開設されたことに よって小松川河川水質への意識がより明確になったものと考える。

次に、1989年の調查結果から、サンプルの度数分布を描くと図11のように なる。河川の水質状況を現状で良いと反応したグルーブと改善すべきと反応 したグループが重なっていて、グループを判別できていない。現状で良いと 反応したグループのサンプル数量の平均值はー1.317で、このグループに属 して、平均値より小さなサンプル数量を持つサンプルの個数は25であった。 そこで、改善グループに属するサンブルもサンブル数量が大きな方から 25 個 だけ選び、これらの意識が明瞙なサンブルの居住地を調べると、図12のよう になって、流域内の全域に分布していることが分かる。

\section{7.まとめ}

以上のように、宮崎市の市街部を流れる小松川を対象として、都市域小河 川に对する流域住民の意識調查を実施し、その解析結果から、流域の住民意 識の把挃、住民意識と地区特性との对応およびこれらの意識の変化を検討し た。これらの結果は、次のようにまとめられる。

(1)意識連鎖は親水 $\rightarrow$ 水質 $\rightarrow そ の$ 他となっていて、治水よりも親水に関心が 高く、調查年による意識構造の基本的な変化はない。(2)数年に一度の頻度で 住環境を破壤する水災害よりも、日常的に住環境を污染している河川水質の

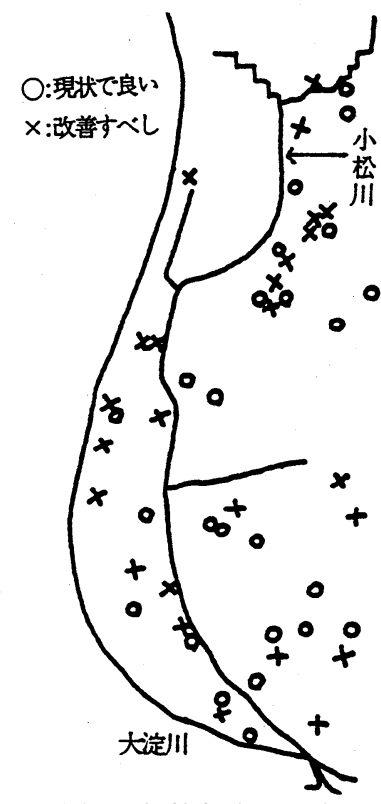

図12 水質意識が明暸な サンプルの居住地 改善を志向し、情緒的な河川空間の創造を志向している。(3)流域住民の志向性はそれぞれの地区の特性と良 く符合する。また水害に対する危機感を明睹に持つ住民は地盤標高の低い右岸側に多い。(4)生活基盤の整備 状況に対する流域住民の意識は、整備事業の進行に応じて敏感に変化する。

おわりになったが、アンケート調查を実施するにあたって、いろいろな方々のご協力をいただいた。ここ に記して謝意を表する。

\section{<参考文献>}

1. 杉尾・安藤 : 小松川流域の洪水制御について、宮崎大学工学部研究報告、 No. 31、pp. 35 41、1985.

2. 建設省九州地方建設局宮崎工事事務所 : 六十年のあゆみ、pp. 213 217、1988.

3. 建設省九州地方建設局宮崎工事事務所：高水速報・台風11号（大淀川）、1989.

4. 宮崎市都市計画公園課：大淀川親水公園、水辺だより、No.10、九州地方計画協会、pp.9、1989.

5. 杉尾・新薗：小松川流域住民の河川に対する意識調查、宮崎大学工学部研究報告、No. 33、pp. 37 47. 1987.

6. 三井大相：アンケートの組みかた、鉄道労働科学研究資料、No. 72-7、pp. 40〜 43、1972.

7. 脇本 -田中 : 多変量統計解析法、BASIC数学3月号、現代数学社、pp. 75 88、1982.

8. 河口至商：多変量解析入門 II、森北出版、pp. 26 44、1978. 